\title{
APLIKASI SURVIVAL LAMA PERAWATAN PASIEN DEMAM BERDARAH DENGUE DI RUMAH SAKIT PERMATA BUNDA MALANG
}

\author{
Survival Analyse Length Of Periode Of Dengue Hemorrhagic Fever Patients In Rumah \\ Sakit Permata Bunda Malang \\ Novia Gita Suriantina \\ Departemen Biostatistika dan Kependudukan Fakultas Kesehatan Masyarakat Universitas \\ Airlangga Alamat korespondensi: \\ Novia Gita Suriantina \\ E-mail: gitadarsono93@gmail.com
}

\begin{abstract}
Survival analysis is a method used to estimate the continuance of an event until a predetermined period. One of survival analysis methods is product limit Kaplan Meier which is employed in this research for the case of medical lenght of period for patients with dengue hemorrhagic fever at Rumah Sakit Permata Bunda Malang. The objectives of this research were to identify the patient's characteristics and analyze the lenght of period of dengue hemorrhagic fever. The independent variables in this research were age, sex, level of platelets and leukocytes. The research population from February 2014 until February 2016 was 119 and 40 samples was done through simple random sampling technique. The research result shows that there was no censored data in 40 samples obtained from medical records. The most susceptible age of patients was 15-59 years old. The number of female patients was greater than male patients. Kaplan Meier's analysis shows that the average lenght of period for dengue hemorrhagic fever patient was 4 days. The independent variables indicating differences in lenght of period was the level of leukocytes which was $p=0.047$, while variables of age, sex, and level of platelets didn't demonstrate differences in length of treatment. Conclusively, there was only one independent variable that indicates differences in lenght of period which was the level of leukocytes.
\end{abstract}

Keywords : product limit Kaplan Meier, lenght of period, dengue hemorrhagic fever 


\begin{abstract}
ABSTRAK
Analisis survival merupakan metode yang digunakan untuk memperkirakan kelangsungan peristiwa sampai periode waktu yang ditentukan. Salah satu metode dalam analisis survival yaitu product limit Kaplan Meier, dalam penelitian ini metode tersebut diterapkan pada permasalahan lama perawatan pasien penderita demam berdarah dengue di Rumah Sakit Permata Bunda Malang yang bertujuan untuk mengidentifikasi karakteristik pasien dan menganalisis lama perawatan DBD. Variabel bebas penelitian adalah usia, jenis kelamin, jumlah trombosit dan nilai leukosit. Jumlah populasi yang menjalani perawatan di Rumah Sakit Permata Bunda Malang pada bulan Februari 2014 sampai Februari 2016 sebanyak 119 yang kemudian diambil 40 sampel berdasarkan teknik simple random sampling. Hasil penelitian yang diperoleh menunjukkan bahwa 40 sampel yang didapatkan dari data rekam medis tidak terdapat data yang tersensor. Usia pasien yang paling banyak yaitu 15-59 tahun. Pasien dengan jenis kelamin perempuan lebih banyak dibandingkan laki-laki. Hasil analisis Kaplan meier menunjukkan lama perawatan pasien DBD rata-rata 4 hari. Variabel bebas yang menunjukkan adanya perbedaan pada lama perawatan yaitu berdasarkan nilai leukosit $p=0,047$, sedangkan untuk variabel usia, jenis kelamin, dan trombosit tidak menunjukkan adanya perbedaan lama perawatan. Kesimpulan yang dapat ditarik adalah hanya terdapat satu variabel yang menunjukkan adanya perberdaan lama perawatan yaitu nilai leukosit.
\end{abstract}

Kata kunci: product limit Kaplan Meier, lama perawatan, demam berdarah dengue

\section{PENDAHULUAN}

Analisis survival atau analisis kesintasan merupakan salah satu cabang statistika yang mempelajari teknik analisis data survival. Tujuannya untuk menaksir probabilitas kelangsungan hidup, kekambuhan, kematian, dan peristiwa lain sampai pada periode waktu tertentu. Data survival adalah data waktu bertahan sampai munculnya kejadian tertentu, misalnya waktu terjadinya infeksi terhadap penyakit tertentu, waktu yang dibutuhkan seorang pasien untuk memberikan respon setelah dilakukan terapi, waktu bertahan hidup bagi penderita penyakit, dan sebagainya. Kejadian yang muncul tidak selalu berupa hal-hal yang buruk tetapi dapat juga berupa sesuatu yang menyenangkan (Rahayu,2012).

Analisis survival terdapat dua metode, yaitu metode untuk parametrik dan nonparametrik. Ada beberapa cara untuk mengestimasi fungsi tahan hidup dengan metode nonparametrik, diantaranya adalah rata-rata ketahanan terkoreksi (corrected survival rates), perbandingan rata-rata yang terstandardisasi (standardized rates and ratio), tabel kehidupan (life table) dan estimasi Product Limit (metode KaplanMeier) (Lawless, 2003).

Salah satu permasalahan yang menyangkut analisis survival sering dijumpai dalam bidang kesehatan, sebagai contoh adalah penyakit Demam Berdarah. Dengue (DBD) yang merupakan penyakit epidemis di Indonesia.

Demam berdarah dengue adalah penyakit yang terdapat pada anak-anak dan dewasa dengan gejala utama demam, nyeri otot dan sendi yang biasanya memburuk setelah dua hari pertama (Hadinegoro dkk, 2004). Penyakit ini merupakan salah satu masalah kesehatan di Indonesia yang terus meningkat hingga tahun 2014.

Jumlah kasus DBD di Indonesia pada tahun 2014 yang dilaporkan sebanyak 100.347 kasus dengan jumlah kematian sebanyak 907 orang (IR/Angka kesakitan 39,8 per 100.000 penduduk dan CFR Angka kematian $=0,9 \%$ ). (profil depkes.go.id)

Menurut Departemen Kesehatan Jawa Timur (2015), pada tahun 2015 terjadi peningkatan kasus DBD sebesar $46 \%$ bila dibandingkan bulan yang sama di tahun 2014. Tingginya kasus terutama kematian akibat DBD tidak terlepas dari kontrol dan pencegahan yang lemah oleh berbagai pihak, khususnya dari pemerintah dan masyarakat. Faktor lain yang berpengaruh adalah belum tersedianya obat spesifik atau vaksin untuk menangani infeksi akibat virus dengue. Penanganan pasien DBD 
menghabiskan waktu yang lama dan biaya kerugian yang relatif besar. Pasien DBD rata-rata menghabiskan waktu rawat inap di rumah sakit selama 4 hari (Tai, 1999). Periode sakit yang dijalani pasien rata-rata 11 hari dengan durasi demam rata-rata selama 6 hari.

Pada penelitian skripsi ini terdapat satu metode parametrik dan nonparametrik. Untuk metode parametrik menggunakan Breslow, yaitu untuk mengetahui perbedaan lama perawatan berdasarkan beberapa faktor terkait lama perawatan pasien DBD dan untuk metode nonparametrik yaitu menggunakan product limit Kaplan Meier.

Pengetahuan akan faktor yang mempengaruhi lama perawatan demam berdarah dengue sangat penting karena hal ini akan menjadi dasar pengambilan keputusan tata laksana penanganan demam berdarah dengue terutama di rumah sakit. Dengan mengetahui faktor mana yang akan menghasilkan perbedaan lama perawatan, maka tenaga kesehatan akan tahu mana yang perlu diintervensi sehingga pasien bisa lebih cepat sembuh. Semakin cepat pasien sembuh maka beban biaya yang harus dikeluarkan juga akan semakin kecil sehingga secara tidak langsung akan dapat mengurangi pembiayaan kesehatan dan meningkatkan derajat kesehatan masyarakat.

Adapun rumah sakit yang menjadi tempat penelitian ini adalah Rumah Sakit Permata Bunda Malang, dimana proporsi penderita demam berdarah rawat inapnya cukup tinggi. Tercatat dari tahun ke tahun mengalami peningkatan. Jumlah pasien DBD pada bulan Februari 2014 hingga Februari 2015 sebanyak 43 orang, sedangkan pasien pada bulan Maret 2015 hingga Februari 2016 sebanyak 76 orang. Tingginya jumlah pasien demam berdarah di rumah sakit ini tentunya akan memudahkan pengambilan sampel, selain itu dengan banyaknya jumlah pasien demam berdarah yang akan ditangani Rumah Sakit Permata Bunda di masa mendatang, maka hasil penelitian ini diharapkan dapat memberi manfaat yang lebih besar baik bagi pihak rumah sakit maupun masyarakat sebagai pasien.

\section{METODE PENELITIAN}

Penelitian ini adalah penelitian observasional karena dalam pengumpulan data tanpa melakukan intervensi atau perlakuan pada responden penelitian. Penelitian ini merupakan penelitian cross sectional, karena setiap responden yang menjadi sampel hanya diobservasi sekali saja dan pengukuran status sampel dilakukan pada saat pengamatan.

Tipe penelitian ini ada penelitian deskriptif analitik karena hanya bermaksud untuk menguraikan suatu keadaan atau peristiwa yang memberikan gambaran mengenai lama perawatan pasien penderita DBD.

Lokasi pada penelitian ini yaitu di Rumah Sakit Permata Bunda jalan Soekarno Hatta no. 75 Malang. Waktu penelitian mulai bulan Maret hingga Juni 2016.

Data yang digunakan berdasarkan hasil rekam medis di Rumah Sakit Permata Bunda Malang mulai bulan Februari 2014 hingga Februari 2016 dengan jumlah populasi 119, kemudian didapat 40 sampel dari populasi berdasarkan teknik simple random sampling.

Variabel utama dalam penelitian ini adalah lama perawatan, sedangkan variabel bebas yaitu usia, jenis kelamin, jumlah trombosit, dan jumlah leukosit.

Data yang diperoleh kemudian disajikan dengan menggunakan product limit Kaplan Meier. Selanjutnya dilakukan analisis untuk mengetahui variable bebas dan terikat dengan menggunakan breslow. Penyajian ini dibantu dengan menggunakan aplikasi komputer.

\section{HASIL PENELITIAN DAN PEMBAHASAN}

Penelitian dilaksanakan di instalasi rekam medis Rumah Sakit Permata Bunda Malang dengan mengambil data seluruh pasien Demam Berdarah Dengue yang terdaftar menjalani perawatan di unit rawat inap mulai 1 Februari 2014 sampai 29 Februari 2016. Penelitian dilakukan dengan melihat status pasien yang didiagnosa DBD 
dan tercantum dalam rekam medis.

Hasil rekam medis yang telah didapatkan kemudian perlu terlebih dahulu dibuat perincian data status penderita yang berguna untuk mengetahui apakah pasien mengalami kematian, pulang paksa, ataupun pulang sesuai waktunya.

Jumlah penderita DBD di RS Permata Bunda mulai bulan Februari 2014 hingga Februari 2016 adalah 119 orang. Kemudian dilakukan perhitungan dengan rumus simple random sampling untuk memperoleh sampel. Didapatkan 40 sampel data rekam medis pasien demam berdarah dengue.

Berdasarkan data yang diperoleh, dari 40 data rekam medis pasien demam berdarah tersebut terdiri dari 40 orang $(100 \%)$ yang merupakan data survival tidak tersensor dan tidak terdapat data yang tersensor. Adapun data survival dapat dilihat pada tabel 5.1

Tabel 1. Data survival pada pasien DBD di RS Permata Bunda bulan Februari 2014 sampai Februari 2016

\begin{tabular}{|l|c|c|}
\hline \multicolumn{1}{|c|}{ Data survival } & Jumlah & $\begin{array}{c}\text { Persentase } \\
(\mathbf{\%})\end{array}$ \\
\hline Tidak Tersensor & 40 & 100 \\
\hline Tersensor & 0 & 0 \\
\hline
\end{tabular}

\section{Analisis Statistik Deskriptif}

Analisis ini digunakan untuk menunjukkan karakteristik dari pasien DBD di Rumah Sakit Permata Bunda

Tabel 2. Analisis lama perawatan, trombosit dan leukosit

\begin{tabular}{|l|c|r|c|c|}
\hline & $\begin{array}{c}\text { Lama } \\
\text { Perawatan } \\
\text { (hari) }\end{array}$ & $\begin{array}{c}\text { Usia } \\
\text { (tahun) }\end{array}$ & $\begin{array}{c}\text { Trombo } \\
\mathbf{s i t} \\
\left(\mathbf{m m}^{3} \text { ) }\right.\end{array}$ & $\begin{array}{c}\text { Leukosit } \\
\text { (mm }^{3} \text { ) }\end{array}$ \\
\hline Mean & 3,78 & 18,55 & 72.000 & 2.775 \\
\hline Std. dev. & 1,38 & 12,38 & 35.465 & 877 \\
\hline Median & 4,00 & 19,00 & 66.000 & 2.650 \\
\hline Min. & 2 & 2 & 22.000 & 1.400 \\
\hline Maks. & & 55 & 142.00 & 4.600 \\
\hline
\end{tabular}

Berdasarkan tabel di atas, analisis deskriptif untuk lama perawatan, usia, jenis kelamin, jumlah trombosit, dan leukosit adalah nilai minimum, nilai maksimum, mean, median dan simpangan Baku. Nilai rata-rata lama perawatan pasien adalah 4 hari dengan simpangan Baku sebesar 2 hari. Nilai rata-rata untuk usia adalah 19 tahun dengan usia pasien paling kecil yaitu 2 tahun dan paling besar 55 tahun. Nilai rata- rata untuk trombosit pasien adalah 72.000, jumlah trombosit paling sedikit dari ke 40 pasien adalah 22.000 dan jumlah paling banyak yaitu 142.000 . Nilai rata-rata leukosit adalah $2.775 / \mathrm{mm}^{3}$, dengan $1400 / \mathrm{mm}^{3}$, dan nilai maksimum $4.600 / \mathrm{mm}^{3}$ untuk leukosit. Nilai median untuk leukosit 2.650 .

\section{Karakteristik Penderita DBD di RS Permata Bunda Berdasarkan Lama Perawatan}

Berdasarkan dari data rekam medis yang tersedia, didapatkan data mengenai lama perawatan DBD sebagai berikut :

Tabel 3. Distribusi Sampel Menurut Lama Perawatan

\begin{tabular}{|l|c|c|}
\hline $\begin{array}{c}\text { Lama } \\
\text { Perawatan } \\
\text { (hari) }\end{array}$ & Frekuensi & Persen (\%) \\
\hline$<4$ & 1 & 47.5 \\
\hline$\geq 4$ & 2 & 52.5 \\
\hline Total & 4 & 100.0 \\
\hline
\end{tabular}

Pada tabel 5.3 menujukkan berapa banyak pasien yang mendapatkan perawatan berdasarkan kurang dan lebih dari rata-rata. Lama perawatan pasien yang paling banyak yaitu lebih dari 4 hari sebesar $52,5 \%$.

\section{Karakteristik Penderita DBD di RS Permata Bunda Berdasarkan Usia}

Berdasarkan dari data rekam medis yang tersedia, didapatkan data mengenai usia pasien DBD di RS Permata Bunda sebagai berikut :

\section{Tabel 4. Distribusi Sampel} Berdasarkan Usia

\begin{tabular}{|c|c|c|}
\hline $\begin{array}{c}\text { Usia } \\
\text { (tahun) }\end{array}$ & Frekuensi & Persen (\%) \\
\hline $0-14$ & 16 & 40.0 \\
\hline $15-59$ & 24 & 60.0 \\
\hline Total & 40 & 100.0 \\
\hline
\end{tabular}


Pada tabel 4 menunjukkan usia yang paling banyak untuk perawatan DBD yaitu pada usia 15-59 tahun sebanyak 24 orang atau sebesar $60 \%$.

\section{Karakteristik Penderita DBD di RS Permata Bunda Berdasarkan Jenis Kelamin}

Berdasarkan dari data rekam medis yang tersedia, didapatkan data mengenai jenis kelamin pasien DBD di RS Permata Bunda sebagai berikut :

Tabel 5. Distribusi Sampel Berdasarkan Jenis Kelamin

\begin{tabular}{|l|c|c|}
\hline $\begin{array}{c}\text { Jenis } \\
\text { Kelamin }\end{array}$ & Frekuensi & Persen (\%) \\
\hline Laki-laki & 19 & 47.5 \\
\hline Perempuan & 21 & 52.5 \\
\hline Total & 40 & 100.0 \\
\hline
\end{tabular}

Pada tabel 5 menunjukkan jumlah pasien DBD yang paling banyak di RS Permata Bunda adalah pasien perempuan.

\section{Karakteristik Penderita DBD di RS} Permata Bunda Berdasarkan Trombosit

Berdasarkan dari data rekam medis yang tersedia, didapatkan data mengenai jumlah trombosit pasien DBD di RS Permata Bunda sebagai berikut :

Tabel 6. Distribusi Sampel Berdasarkan Jumlah Trombosit

\begin{tabular}{|l|c|c|}
\hline $\begin{array}{c}\text { Jumlah } \\
\text { Trombosit } \\
\left(\mathbf{m m}^{\mathbf{3}}\right)\end{array}$ & Frekuensi & Persen (\%) \\
\hline$<100.000$ & 30 & 7 \\
\hline$\geq 100.000$ & 10 & 2 \\
\hline Total & 40 & 10 \\
\hline
\end{tabular}

Berdasarkan tabel 5.6, jumlah pasien yang paling banyak yaitu yang memiliki jumlah trombosit dibawah $100.000 \mathrm{~mm}^{3}$.

\section{Karakteristik Penderita DBD di RS Permata Bunda Berdasarkan Nilai Leukosit}

Berdasarkan dari data rekam medis yang tersedia, didapatkan data mengenai nilai leukosit pasien DBD di RS Permata
Bunda sebagai berikut :

Tabel 7. Distribusi Sampel Berdasarkan Nilai Leukosit

\begin{tabular}{|l|c|c|}
\hline Leukosit $\left(\mathbf{m m}^{3}\right)$ & Frekuensi & Persen (\%) \\
\hline$<2650$ & 20 & 50.0 \\
\hline$\geq 2650$ & 20 & 50.0 \\
\hline Total & 40 & 100.0 \\
\hline
\end{tabular}

Dari tabel 7 diketahui bahwa sebanyak 20 pasien DBD memiliki nilai leukosit di bawah rata-rata $\left(<2650 / \mathrm{mm}^{3}\right)$ dan 20 orang lainnya memiliki kadar leukosit lebih dari $2650 / \mathrm{mm}^{3}$

\section{Analisis Kaplan Meier Lama Perawatan Pasien Demam Berdarah Dengue}

Berikut adalah hasil analisis frekuensi lama perawatan pasien DBD di RS Permata Bunda

Tabel 8. Frekuensi Lama Perawatan

\begin{tabular}{|c|c|c|c|}
\hline $\begin{array}{c}\text { Lama } \\
\text { Perawatan }\end{array}$ & Frekuensi & Estimasi & $\begin{array}{l}\text { Waktu } \\
\text { Survival }\end{array}$ \\
\hline 2 hari & 9 & 0,7 & \multirow{5}{*}{$\begin{array}{l}\text { Rata-rata } \\
3,78 \text { hari } \\
\text { Median } \\
4 \text { hari }\end{array}$} \\
\hline 3 hari & 10 & 0,5 & \\
\hline 4 hari & 8 & 0,3 & \\
\hline 5 hari & 7 & 0,1 & \\
\hline 6 hari & 6 & 0 & \\
\hline Total & 40 & & \\
\hline
\end{tabular}

Dari 40 pengamatan terhadap penderita DBD, tidak terdapat pengamatan yang disensor. Dari data tersebut kemudian dianalisis dengan menggunakan product limit Kaplan Meier. Secara umum analisis survival penderita DBD bila dilihat dari rata-rata lama perawatannya adalah 3,78 hari.

Proporsi kumulatif lama perawatan penderita DBD yang lebih dari 2 hari sebesar $77,5 \%$ dan proporsi kumulatif pasien yang dirawat lebih dari 6 hari sebesar $0 \%$. Hal ini menunjukkan bahwa probabilitas penderita untuk lama perawatan lebih dari 6 hari adalah sebesar 0. Estimasi median lama perawatan pasien DBD adalah 4 hari. 


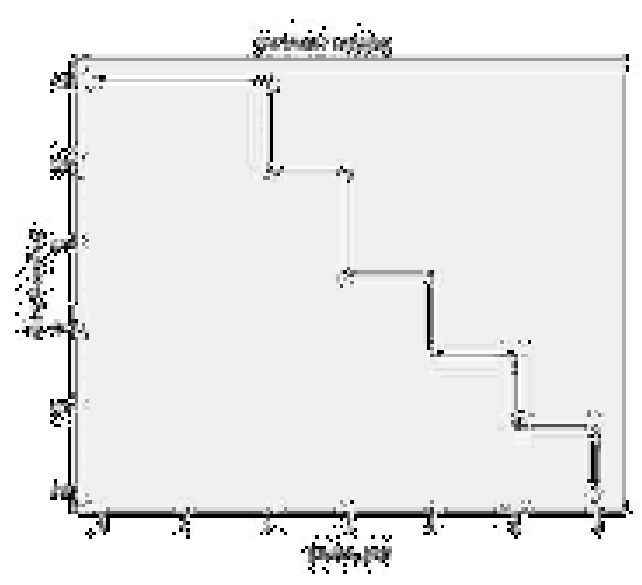

Gambar 1. Fungsi Survival Lama Perawatan Pasien Penderita Demam Berdarah Dengue

\section{Perbedaan Lama Perawatan Menurut Usia}

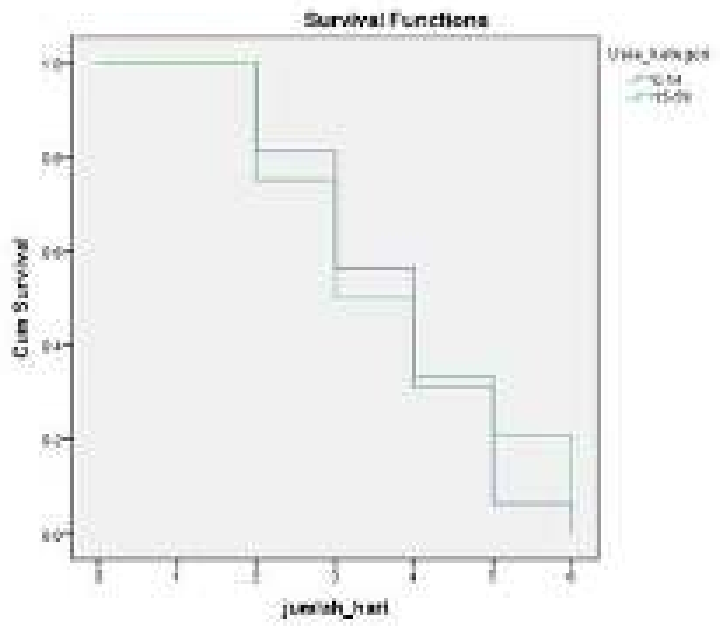

Gambar 2. Fungsi Survival Lama Perawatan Pasien Penderita DBD Berdasarkan Usia

Pasien DBD yang memiliki usia 0-14 tahun mempunyai proporsi kumulatif lama perawatan pada waktu perawatan lebih dari 2 hari sebesar $81,3 \%$ dan pada lebih dari 6 hari sebesar 0. Estimasi median lama perawatan untuk pasien yang memiliki usia 0-14 tahun adalah 3 hari. Pasien yang berusia 15-59 tahun mempunyai proporsi kumulatif lama perawatan pada waktu perawatan paling sedikit 2 hari sebesar $75 \%$ dan pada lebih dari 6 hari adalah 0 . Estimasi median lama perawatan untuk pasien berusia 15-59 tahun adalah 3 hari.

Tabel. 9. Perbedaan lama perawatan berdasarkan usia pasien

\begin{tabular}{|l|c|c|c|c|}
\hline Usia & Median & Min. & Maks. & $\begin{array}{c}\text { Breslow } \\
\text { Test }\end{array}$ \\
\hline $0-14$ & 4 hari & 2 th & 12 th & $\begin{array}{l}\chi^{L}=0,000 \\
\mathrm{p}=0,989\end{array}$ \\
\hline $\begin{array}{l}15- \\
59\end{array}$ & 3 hari & 16 th & 55 th & \\
\hline
\end{tabular}

Pada uji statistik perbandingan distribusi pasien usia 0-14 tahun dengan pasien usia 15-59 tahun menunjukkan $\mathrm{p}=0,989$. Dengan menggunakan $\alpha=0.05$, maka tidak ada perbedaan lama perawatan antara pasien usia 0-14 dengan pasien usia 15-59.

\section{Perbedaan Lama Perawatan Menurut Jenis Kelamin}

Berikut adalah hasil analisis survival lama perawatan pasien DBD menurut jenis kelamin.

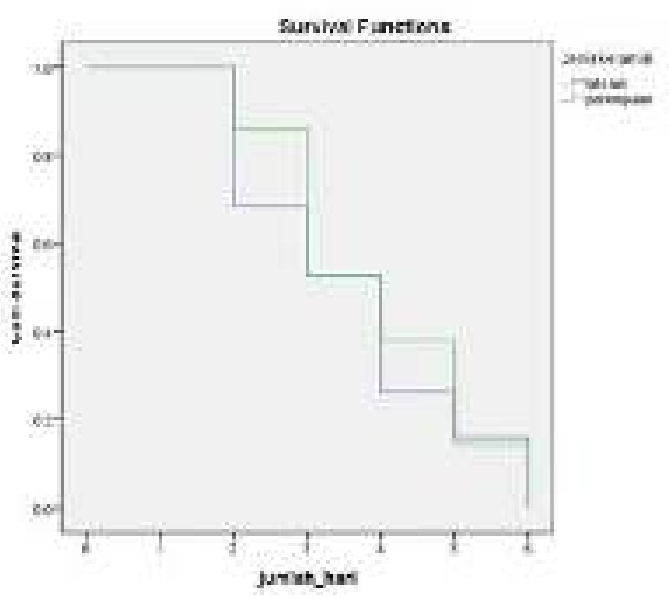

Gambar 3. Fungsi Survival Lama Perawatan Pasien Penderita DBD Berdasarkan Jenis Kelamin

Pasien DBD yang berjenis kelamin laki-laki mempunyai proporsi kumulatif pada waktu perawatan lebih 2 hari sebesar $71,4 \%$ dan pada waktu lebih dari 6 hari sebesar 0. Estimasi median lama perawatan untuk pasien berjenis kelamin laki-laki yaitu 4 hari.

Pasien berjenis kelamin perempuan mempunyai proporsi kumulatif pada waktu perawatan lebih dari 2 hari sebesar 0,842 dan pada waktu lebih dari 6 hari adalah 0 . Estimasi median lama perawatan untuk pasien berjenis kelamin perempuan adalah 3 hari. 
Tabel 10. Perbandingan lama perawatan berdasarkan jenis kelamin

\begin{tabular}{|c|r|c|}
\hline $\begin{array}{c}\text { Jenis } \\
\text { Kelamin }\end{array}$ & Median & Breslow Test \\
\cline { 1 - 2 } Laki-Laki & 4,000 & $\begin{array}{l}\chi^{\alpha}=0,443 \\
\mathrm{p}=0,506\end{array}$ \\
\hline Perempuan & 3,000 & \\
\hline
\end{tabular}

Pada uji statistik perbandingan lama perawatan pasien berdasrkan jenis kelamin laki-laki dengan pasien perempuan menunjukkan $\mathrm{p}=0.506$. Dengan menggunakan $\alpha=0.05$, maka tidak ada perbedaan lama perawatan antara pasien berjenis kelamin laki-laki dan perempuan.

\section{Perbedaan Lama Perawatan Menurut Jumlah Trombosit}

Berikut adalah hasil analisis survival lama perawatan pasien DBD menurut jumlah trombosit

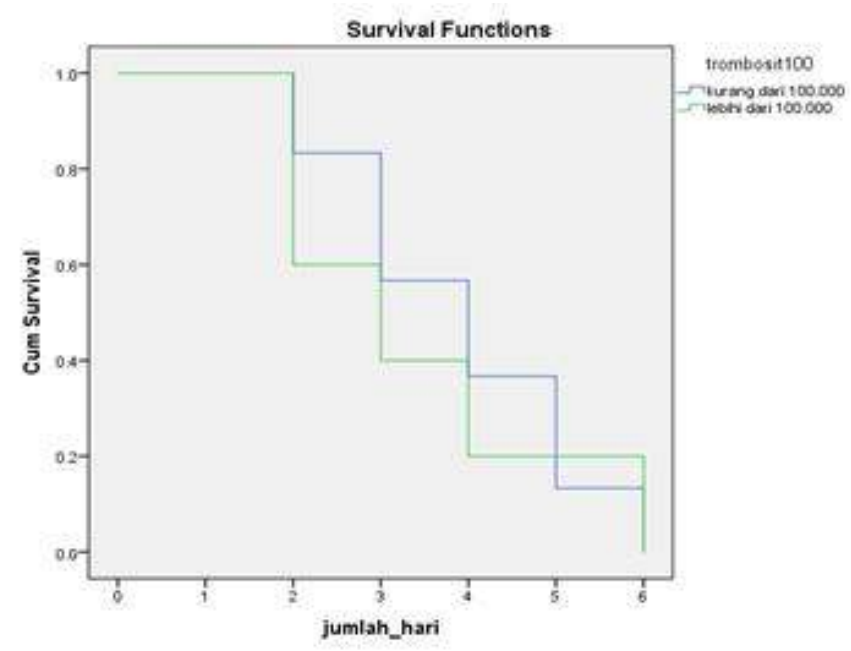

Gambar 4. Fungsi Survival Lama Perawatan Pasien Penderita DBD Berdasarkan Trombosit

Diketahui bahwa pasien DBD dengan jumlah trombosit di kurang dari 100.000 mempunyai proporsi kumulatif pada waktu perawatan lebih dari 2 hari sebesar 83,3\% dan pada waktu lebih dari 6 hari sebesar 0 . Estimasi median lama perawatan untuk pasien dengan jumlah trombosit kurang dari rata-rata adalah 4 hari.

Pasien dengan jumlah trombosit di atas rata-rata mempunyai proporsi kumulatif pada waktu perawatan lebih dari 2 hari sebesar $60 \%$ dan pada waktu paling lama 6 hari adalah 0. Estimasi median lama perawatan untuk pasien dengan jumlah trombosit lebih dari rata-rata yaitu 3 hari.

Tabel 11. Perbandingan lama perawatan berdasarkan jumlah trombosit

\begin{tabular}{|l|c|c|c|l|}
\hline $\begin{array}{c}\text { Trombosit } \\
\left(\mathbf{m m}^{\mathbf{3}} \mathbf{)}\right.\end{array}$ & Median & Min. & Maks. & $\begin{array}{l}\text { Breslow } \\
\text { Test }\end{array}$ \\
\hline$<$ & 4 & 22.000 & 95.000 & $\begin{array}{l}\chi^{L} \\
=1,275\end{array}$ \\
\hline 100.000 & 3 & $\begin{array}{c}103.00 \\
0\end{array}$ & $\begin{array}{c}142.00 \\
0\end{array}$ & $\mathrm{p}=0,259$ \\
\hline 100.000 & & \\
\hline
\end{tabular}

Pada uji statistik perbandingan lama perawatan berdasarkan jumlah trombosit pasien menunjukkan $p=0.259$. Dengan menggunakan $\alpha=0.05$, maka tidak ada perbedaan lama perawatan pasien DBD menurut jumlah trombosit pada pasien.

\section{Perbedaan Lama Perawatan Menurut Nilai Leukosit}

Berikut adalah hasil analisis survival lama perawatan pasien DBD menurut nilai leukositnya.

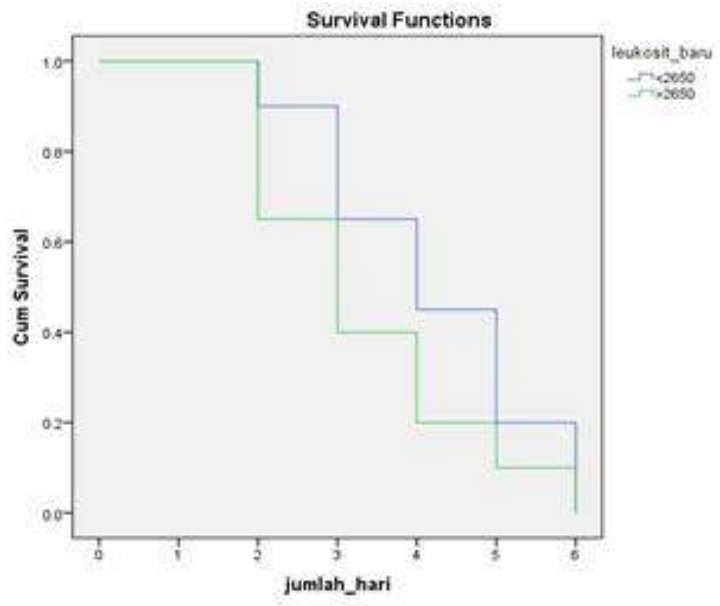

Gambar 5. Fungsi Survival Lama Perawatan Pasien Penderita DBD Berdasarkan Leukosit

Pasien DBD dengan nilai leukosit di bawah rata-rata $(2650 / \mathrm{mm} 3)$ mempunyai proporsi kumulatif pada waktu perawatan lebih dari 2 hari sebesar $90 \%$ dan pada waktu lebih dari 6 hari sebesar 0. Estimasi median lama perawatan untuk pasien dengan nilai leukosit di bawah rata-rata adalah 4 hari.

Sedangkan untuk pasien dengan nilai leukosit di atas rata-rata mempunyai proporsi kumulatif pada waktu perawatan lebih dari 2 hari sebesar $65 \%$ dan pada 
waktu lebih dari 6 hari adalah 0. Estimasi median lama perawatan untuk pasien dengan nilai leukosit normal adalah 3 hari.

Tabel 12 Perbandingan lama perawatan berdsarkan nilai leukosit

\begin{tabular}{|c|c|c|c|c|}
\hline $\begin{array}{c}\text { Leu } \\
\text { kosit }\end{array}$ & Median & Min. & Maks. & $\begin{array}{c}\text { Breslow } \\
\text { Test }\end{array}$ \\
\hline $\begin{array}{l}< \\
2650\end{array}$ & 4 & 1.400 & 2.600 & $\begin{array}{l}\chi^{2}= \\
3,958\end{array}$ \\
\hline $\begin{array}{l}\geq \\
2650\end{array}$ & 3 & 2.700 & 4.600 & $\begin{array}{l}p= \\
0,047\end{array}$ \\
\hline
\end{tabular}

Pada uji statistik perbandingan distribusi nilai leukosit di bawah rata-rata dengan nilai leukosit di atas rata-rata menunjukkan $\mathrm{p}=0.047$. Dengan menggunakan $\alpha=0.05$, maka ada perbedaan lama perawatan antara pasien dengan leukosit di bawah rata-rata dengan pasien dengan nilai leukosit di atas rata-rata.

Berdasarkan data yang telah diperoleh dapat diketahui bahwa tidak ada pasien penderita DBD yang termasuk di dalam kriteria tersensor, karena seluruh pasien di RS Permata Bunda tidak terdapat pasien yang hilang, pulang paksa, dan meninggal.

\section{Karakteristik Penderita DBD di RS Permata Bunda}

Pada penelitian ini terdapat 5 variabel bebas yaitu variabel usia, jenis kelamin, jumlah trombosit dan jumlah leukosit. Kelima variabel tersebut masing-masing dianalisis pengaruhnya dengan variabel dependen yaitu lama perawatan.

Berdasarkan tabel 2 analisis deskriptif yang digunakan yaitu nilai minimum, maksimum, median, mean dan standar deviasi. Analisis deskriptif lama perawatan menunjukkan bahwa rata-rata pasien DBD di RS Permata Bunda adalah 4 hari.

Apabila dilihat dari karakteristik usia pasien DBD di RS Permata Bunda, dimulai dari rentan usia 2 tahun sampai 54 tahun. Pasien paling banyak yaitu pada usia 15-59 tahun sebanyak 27 orang yang terdiagnosa DBD. Hal tersebut serupa dengan buletin jendela epidemiologi (2010), penyakit DBD dapat terjadi pada usia berapapun, namun lebih banyak pada usia produktif yaitu 15-59 tahun. Selain itu pada penelitian Fa'rifah dan Purhadi (2012) juga mengungkapkan bahwa pasien DBD yang berusia 15-59 tahun lebih banyak dibandingkan pasien usia muda (0-14 tahun).

Berdasarkan jenis kelamin pasien penderita DBD di RS Permata Bunda, pasien dengan jenis kelamin perempuan lebih banyak dibandingkan pasien laki-laki dengan perbandingan persentase 52,5\% dan $47,5 \%$. Hasil dari penelitian ini sama dengan penelitian yang dilakukan Nopianto (2012), bahwa pasien perempuan untuk penyakit demam berdarah dengue lebih banyak dibandingkan pasien laki-laki. Menurut Kasper (2009), perempuan lebih berisiko terkena penyakit DBD dikarenakan dinding kapiler pada wanita lebih cenderung dapat meningkatkan permeabilitas kapiler dibandingkan dengan laki-laki.

Berdasarkan hasil distribusi pasien demam berdarah dengue menurut pemeriksaan klinis yaitu trombosit dan leukosit. Pemeriksaan laboratorium berdasarkan trombosit pasien demam berdarah di rumah sakit Permata Bunda didapatkan rata-rata jumlah trombosit 66.000. Jumlah trombosit dari 40 sampel menunjukkan hasil pasien yang dengan jumlah trombosit di atas 100.000 lebih banyak dibandingkan jumlah trombosit pasien dibawah 100.000. Sebanyak 10 orang dengan hasil laboratorium jumlah trombosit di atas 100.000, sedangkan 30 orang lainnya menunjukkan hasil trombosit dibawah 100.000. Hal tersebut serupa dengan penelitian yang dilakukan oleh Siregar (2006), bahwa jumlah trombosit pasien yang di bawah $100.000 / \mathrm{mm}^{3}$ lebih banyak dibandingkan pasien dengan jumlah trombosit di atas $100.000 / \mathrm{mm}^{3}$.

Pemeriksaan laboratorium yang kedua untuk memutuskan pasien terdiagnosa DBD yaitu leukosit. Hasil dari analisis penelitian, nilai rata-rata leukosit pasien di RS Permata Bunda yaitu 2650, dari hasil tersebut digunakan untuk membagi kategori leukosit menjadi dua, yaitu pasien dengan nilai leukosit di bawah 
rata-rata $(<2650)$ dan pasien dengan nilai leukosit di atas rata-rata. Distribusi kedua kategori tersebut terbagi sama rata, yaitu masing-masing 20 orang.

\section{Analisis Kaplan Meier Lama Perawatan Pasien Demam Berdarah Dengue}

Terdapat beberapa faktor yang dapat mempengaruhi terjadinya penyakit DBD. Menurut faktor yang dapat mempengaruhi yaitu usia, jenis kelamin, trombosit dan leukosit. Faktor tersebut yang secara tidak langsung akan dapat mempengaruhi lama perawatan penyakit DBD di rumah sakit. Berdasarkan dari tabel 8 , rata-rata lama perawatan pasien penderita DBD yaitu 3,78 hari atau 4 hari. Hal tersebut serupa dengan penelitian yang dilakukan oleh Tamimi (2012), bahwa rata-rata perawatan pasien DBD adalah 4 hari. Apabila dilihat berdasarkan modus lama perawatannya yaitu 3 hari, sebanyak 10 orang dari 40 sampel. Dilihat dari estimasi lama perawatan 2 hingga 6 hari terus menurun, hal ini berarti pasien demam berdarah dengue tidak membutuhkan waktu perawatan lebih dari 6 hari, yaitu dengan nilai estimasi 0,00 .

\section{Perbedaan Lama Perawatan Menurut Usia}

Lama perawatan pada usia 0-14 tahun paling banyak lebih dari 3 hari dan sebelum 6 hari, dengan proporsi kumulatif lama perawatan 3 hari yaitu $56,3 \%$, proporsi kumulatif 4 hari yaitu 31,3\% dan proporsi kumulatif lama perawatan lebih dari 5 hari $6,3 \%$. Sedangkan lama perawatan pada usia 15-59 tahun paling banyak lebih dari 2 hari dan kurang dari 4 hari dengan proporsi kumulatif lebih dari 2 hari yaitu $75 \%$ dan lebih dari 3 hari yaitu 50\%. Usia minimum pasien di RS Permata Bunda yaitu 2 tahun, dan usia maksimum yaitu 55 tahun.

Berdasarkan tabel 9 diketahui bahwa hasil analisi Kaplan meier lama perawatan menurut usia memiliki nilai $\mathrm{p}=0,989$, yang berarti bahwa tidak ada perbedaan antara usia pasien 0-14 tahun dengan 15-59 tahun terhadap lama perawatan DBD. Hal tersebut serupa dengan penelitian Nopianto
(2012) yang menunjukkan tidak ada pengaruh usia terhadap lama perawatan pasien inap DBD.

\section{Perbedaan Lama Perawatan Menurut Jenis Kelamin}

Pada beberapa penelitan menyebutkan bahwa jenis kelamin berpengaruh terhadap kejadian DBD yang secara tidak langsung berpengaruh terhadap perawatan. Menurut Kasper (2009), perempuan lebih berisiko terhadap penyakit DBD dibandingkan laki-laki, karena diding kapiler pada wanita cenderung lebih dapat meningkatkan permeabilitas kapiler dibanding laki-laki. Hal tersebut sesuai dengan jumlah pasien perempuan di RS Permata Bunda lebih banyak dibandingkan jumlah pasien laki-laki.

Berdasarkan tabel 10 jenis kelamin menunjukkan nilai $\mathrm{p}=0,506$, yang berarti tidak ada perbedaan lama perawatan menurut jenis kelaminnya. Hasil dari penelitian ini serupa dengan penelitan Sumanto (2007) yang menyatakan bahwa tidak terdapat pengaruh antara jenis kelamin dan lama rawat inap. Selain itu penelitian yang dilakukan oleh Perwira (2011) juga menyatakan bahwa tidak terdapat perbedaan lama perawatan menurut jenis kelamin pasien.

\section{Perbedaan Lama Perawatan Menurut Jumlah Trombosit dan Leukosit}

Kriteria labolatorium dari DBD dilihat melalui, jumlah trombosit dan nilai leukosit. Berdasarkan hasil analisis Product Limit Kaplan Meier lama perawatan menurut jumlah trombosit, modus lama perawatan pasien DBD dengan jumlah trombosit kurang dari 100.000 yaitu 3 hari dengan proporsi kumulatif 56,7\%, sedangkan untuk pasien dengan jumlah trombosit lebih dari 100.000 yaitu 4 hari dengan proporsi kumulatif $60 \%$. Hasil dari breslow test menunjukkan $\mathrm{p}=0,259$ dengan $\alpha=0,05$, maka tidak ada perbedaan lama perawatan menurut jumlah trombosit pasien di bawah 100.000 dengan jumlah trombosit di atas 100.000. Hal tersebut serupa dengan penelitian yang dilakukan oleh Sarah (2016), bahwa tidak ada perbedaan lama perawatan menurut jumlah trombosit 
pasien.

Pemeriksaan laboratorium untuk mendiagnosa pasien DBD, penghitungan leukosit juga sama berpengaruhnya seperti trombosit karena leukosit diperhitungkan dalam menentukan prognosis pada fasefase awal infeksi. Pada penelitian ini analisis statistik uji perbedaan nilai leukosit menunjukkan adanya perbedaan yang signifikan terhadap lama perawatan. Sesuai pada tabel 12 yang menunjukkan hasil yaitu 0,047 .

\section{SIMPULAN DAN SARAN}

\section{Simpulan}

Berdasarkan hasil penelitian ini, dapat disimpulkan bahwa analisis survival lama perawatan pasien penderita DBD di RS Permata Bunda dengan menggunakan product limit Kaplan Meier diperoleh ratarata waktu survival adalah 4 hari, dengan rentang waktu minimum untuk perawatan yaitu 2 hari dan maksimum 6 hari. Berdasarkan 4 variabel yang digunakan, terdapat satu vairabel yang bisa mempengaruhi perbedaan lama perawatan pasien DBD yaitu nilai leukosit.

\section{Saran}

Adanya perbedaan lama perawatan menurut leukosit diharapkan dapat menjadi suatu acuan dan pertimbangan bagi pihak rumah sakit dalam menentukan tindakan yang berhubungan dengan perawatan pasien DBD. Data survival hendaknya lebih dimanfaatkan dengan melakukan statistik uji yang tepat untuk mengetahui suatu informasi yang dapat digunakan sebagai acuan dalam menentukan suatu kebijakan kesehatan untuk meningkatkan mutu pelayanan rumah sakit.

\section{DAFTAR PUSTAKA}

Collet, D., 2003, Modelling Survival Data in Medical Research. London : Chapman \& Hall

Farifah, R. Y., \& Purhadi. (2012). Analisis Survival Faktor-Faktor yang mempengaruhi Laju Kesembuhan Pasien Penderita Demam Berdarah Dengue (DBD) di RSU Haji
Surabaya dengan regresi Cox. Jurnal Sains dan Seni ITS Vol.1 No. 1. Tersedia di : http://download.portalgaruda.org/ arti

cle.php? article $=60981 \& \mathrm{val}=4187$ [13 Mei 2016]

Hadinegoro SRH, Soegijanto S, Wuryadi S, Suroso T. 2004. Tatalaksana Demam Berdarah Dengue di Indonesia. Jakarta: Direktorat Jenderal Pengendalian Penyakit dan Penyehatan Lingkungan. Tersedia di :https://silahuddinm.files.wordpre ss.c om $/ 2013 / 02 / b k 2007-g 4 . p d f$ [30 April 2016]

Soedarmo SP, Garna H, Hadinegoro SRS. 2002.Buku Ajar Ilmu Kesehatan Anak dan Penyakit Tropis. Edisi pertama. Jakarta: Balai Penerbit Fakultas Kedokteran Universitas Indonesia;.h.176-208.

Hougaard, P. 2001. Analysis of Multivariate Survial Data. New York : Springer Science and Bussiness media Inc

Kasper, D.L., Braunwald, E., Fauci, A.S. 2009. Harrison's Principle of Internal Medicine. $17^{\text {th }}$ ed. New York : McGraw-Hill Medical Publishinng Division.p.1239

Kementerian Kesehatan Republik Indonesia. 2010. Buletin Jendela Epidemiologi. Pusat Data dan Surveilans Epidemiologi.

Kementerian Kesehatan Republik Indonesia. 2010. Profil Kesehatan Indonesia 2010. terdapat di :http://www.depkes.go.id/downlo ads/ PROFIL_KESEHATAN_ INDONESIA_2010.pdf

Kementerian Kesehatan Republik Indonesia. 2014. Profil Kesehatan Indonesia 2014. terdapat di :http://www.depkes.go.id/downlo ads/ PROFIL_KESEHATAN_ INDONESIA_2014.pdf

Klein, J.P dan M.L. Moeschberger. 1997. Survival Analysis : Techniques for Censored and Truncated Data. New York : Springer-Verlag New York Inc 
Kleinbaum, D.G. dan Klein, M., 2005, Survival Analysis: A Self Learning Text. New York : Springer

Lawless, J. F. 2003. Statistical Models and Method for Lifetime Data.2nd ed. New York: John Wiley \& Sons. Tersedia di http://samples.sainsburysebooks.c o. uk/9781118031254_sample_3793 19. pdf [30 April 2016]

Lee, E.T. \& Wang, J.W. 2003. Statistical Methods for Survival Data Analysis. $3^{\text {rd }}$ ed. New Jersey: John Wiley \& Son Inc Public. Tersedia di : http://evunix.uevora.pt / pinfante/eb1011/Maths\%20\&\% 20

Stats $\% 20 \% 20$ Statistical $\% 20$ Meth ods $\% 20$ for $\% 20$ Survival $\% 20$ Data $\% 20 \mathrm{An}$ alysis $\% 20 \% 203 \mathrm{rd}, 2003 \% 20 \% 5 \mathrm{~B}$ Wil ey\%5D.pdf [7 Mei 2016]

Murti, B. 1997. Prinsip dan Metode Riset Epidemiologi. Yogyakarta : Gadjah Mada UniversityPress.

Nopianto, H. 2012. Faktor - Faktor Yang Berpengaruh Terhadap Lama Rawat Inap Pada Pasien Demam Berdarah Dengue Di RSUP DR Kariadi Semarang. Karya Tulis Ilmiah. Universitas Diponegoro. Tersedia di $<$ https://core.ac.uk/download/pdf/ 11 735864.pdf $>$ [12 April 2016] Rahayu, N., Setiawan, A., Mahatma, T. 2012. Analisis Regresi Cox Propotional Hazard Pada Ketahanan Hidup Pasien diabetes Mellitus. Seminar Nasional Matematika 2012. Tersedia di $<$ http://ris.uksw.edu/download/ma kal ah /kode/M00706> [5 April 2016]

Siregar, R.S. 2006. Karakteristik Penderita Demam Berdarah Dengue (DBD) Yang Dirawat Inap Di RSU Tembakau Deli Medan Tahun 2001-2005. Skripsi. Universitas
Sumatera Utara. Tersedia di < http://repository.usu.ac.id/handle/ 123456789/32599> [12 April 2016] Tamimi, K. 2012. Karakteristik Penderita Demam Berdarah Dengue (DBD) Yang Rawat Inap di RSUD Lubuh Pakam Tahun 2011. Skripsi. Universitas Sumatera Utara. Tersedia $\mathrm{di}<\mathrm{http}: / /$ repository.usu.ac.id/hand le/123456789/ 34504>[14 Mei 2016]

Tamimi, K. 2012. Karakteristik Penderita Demam Berdarah Dengue (DBD) Yang Rawat Inap di RSUD Lubuh Pakam Tahun 2011. Skripsi. Universitas Sumatera Utara. Tersedia di<http://repository.usu.ac.id/hand le/123456789/ 34504>[14 Mei 2016] 
JURNAL ILMIAH KESEHATAN MEDIAHUSADA ｜ VOLUME 05/NOMOR 02/OKTOBER 2016 